\title{
Impact of Water Pollution on Aspects of Aquatic Life in the Euphrates at Kufa City
}

\author{
Hasan Mahdi Mohammed Al-Khateeb ${ }^{1}$ \\ Assistant Professor, Department of Civil Engineering, Faculty of Engineering, University of Kufa, Iraq ${ }^{1}$
}

\begin{abstract}
The Euphrates river in Iraq face a challenge of receiving a verity of pollutants, mainly come from wastes discharged into the river. Although industrial effluents and drainage from farm lands impose considerable pollution load, effluents of municipal wastewater treatment plants represent an effective source of pollution to the Euphrates. The study area of this paper was selected as $12.55 \mathrm{~km}$ long of the Euphrates River of the branch "Shatt Al-Kufa" just downstream Kufa city within Najaf Governorate in the middle of Iraq. Upper and lower boundaries of the study area were water monitoring stations belong to the Iraqi Ministry of Water Resources. The upper (upstream) boundary was Kufa Station, while the lower (downstream) boundary was Manathera Station. Water temperature, $\mathrm{pH}$ and electric conductivity (EC) were measured in the field. Water samples collected daily from the river at the two stations (Kufa and Manatherah) along three intervals as 23-30 April 2019, 1-7 July 2019 and 10-18 November 2019, and tested in lab for total dissolved solids (TDS), total suspended solid (TSS), dissolved oxygen (DO), biochemical Oxygen demand $\mathrm{BOD}_{5}$, calcium (Ca), magnesium $(\mathrm{Mg})$, sulphate $\left(\mathrm{SO}_{4}\right)$, Nitrite $\left(\mathrm{NO}_{2}\right)$, Nitrate $\left(\mathrm{NO}_{3}\right)$ and phosphate $\left(\mathrm{PO}_{4}\right)$. Observations were made at dates $23^{\text {rd }}$ April, $1^{\text {st }}$ July and $10^{\text {th }}$ November 2019 for some aspects of aquatic life like plants, fish and amphibians. According to results and observations of this study, the effluent of Kufa wastewater treatment plant had a slight local effect on some water quality parameters of the Euphrates river like EC, TDS, $\mathrm{BOD}$, $\mathrm{DO}, \mathrm{PO}_{4}, \mathrm{SO}_{4}, \mathrm{NO}_{2}$ and $\mathrm{NO}_{3}$ that affected some aspects of aquatic life downstream the discharge point of the plant. Some kinds of fish like Sharpeyi Barbus, Barbus xanthoptrrus, Barbus grypus, luteus Barbus and Liza abu were observed with lower number just downstream the effluent discharge point.
\end{abstract}

Keywords: Impact, Water Pollution, Aquatic, Euphrates.

\section{INTRODUCTION}

Iraq relies on surface water rather than groundwater for different uses like drinking, irrigation and industry. Surface water bodies like reservoirs, lakes, marshes and streams represent 15\% of the total area of Iraq [1]. However, the two rivers Euphrates and Tigris represent the most important resources feeding other surface water bodies. They pass through Iraq and supply cities with drinking water and farms with irrigation water after passing through Turkey and Syria. The annual average discharge of the Euphrates River is continuing to decline due to the construction of large dams in upstream countries Turkey (GAP project) and Syria [2] [3]. In addition to this challenge, the Euphrates face another challenge of receiving a verity of pollutants, mainly come from wastes discharged into the river. Although industrial effluents and drainage from farm lands impose considerable pollution load, effluents of municipal wastewater treatment plants represent an effective source of pollution to the Euphrates [4]. Constructing the dams in Turkey with associated filling periods lead to decrease flow rates, which in turn, lead to decrease dilution factor of the river for the pollutants received. As a result of flow rate reduction, salinity is reported to increase in the river [1], however, organic pollutants and heavy metals come mainly from wastewater treatment plants effluent represent important concern [5] [6] [7] [8].

Some previous studies directed towards tracking the effect of certain pollution sources on water quality in the river by means of mathematical models and GIS. Such sources were often to be wastewater treatment plant effluent [9],[10],[11]. However, other studies focused on biological effect of the pollution [12], [13], [14]. Others investigated the climatic and thermal effect on river water quality [15], [16]. This paper is focusing on the effect of water pollution on some aspects of aquatic life in the Euphrates River within Kufa city.

\section{STUDY AREA}

The study area was selected as $12.55 \mathrm{~km}$ long of the Euphrates River of the branch "Shatt Al-Kufa" just downstream Kufa city within Najaf Governorate in the middle of Iraq. Upper and lower boundaries of the study area were water monitoring stations belong to the Iraqi Ministry of Water Resources. The upper (upstream) boundary was Kufa Station located at $32^{\circ} 0^{\prime} 58.73 " \mathrm{~N}, 44^{\circ} 25^{\prime} 32.50^{\prime \prime} \mathrm{E}$, while the lower (downstream) boundary was Manathera Station at $31^{\circ} 55^{\prime} 24.41^{\prime \prime N}, 44^{\circ} 29^{\prime} 22.11^{\prime \prime E}$. The Euphrates is divided at $15 \mathrm{~km}$ north of Kufa city into two branches; Shat Al-Kufa branch and Abbassiyah branch, Fig. 1. 
International Advanced Research Journal in Science, Engineering and Technology

Vol. 7, Issue 8, August 2020

DOI 10.17148/IARJSET.2020.7825
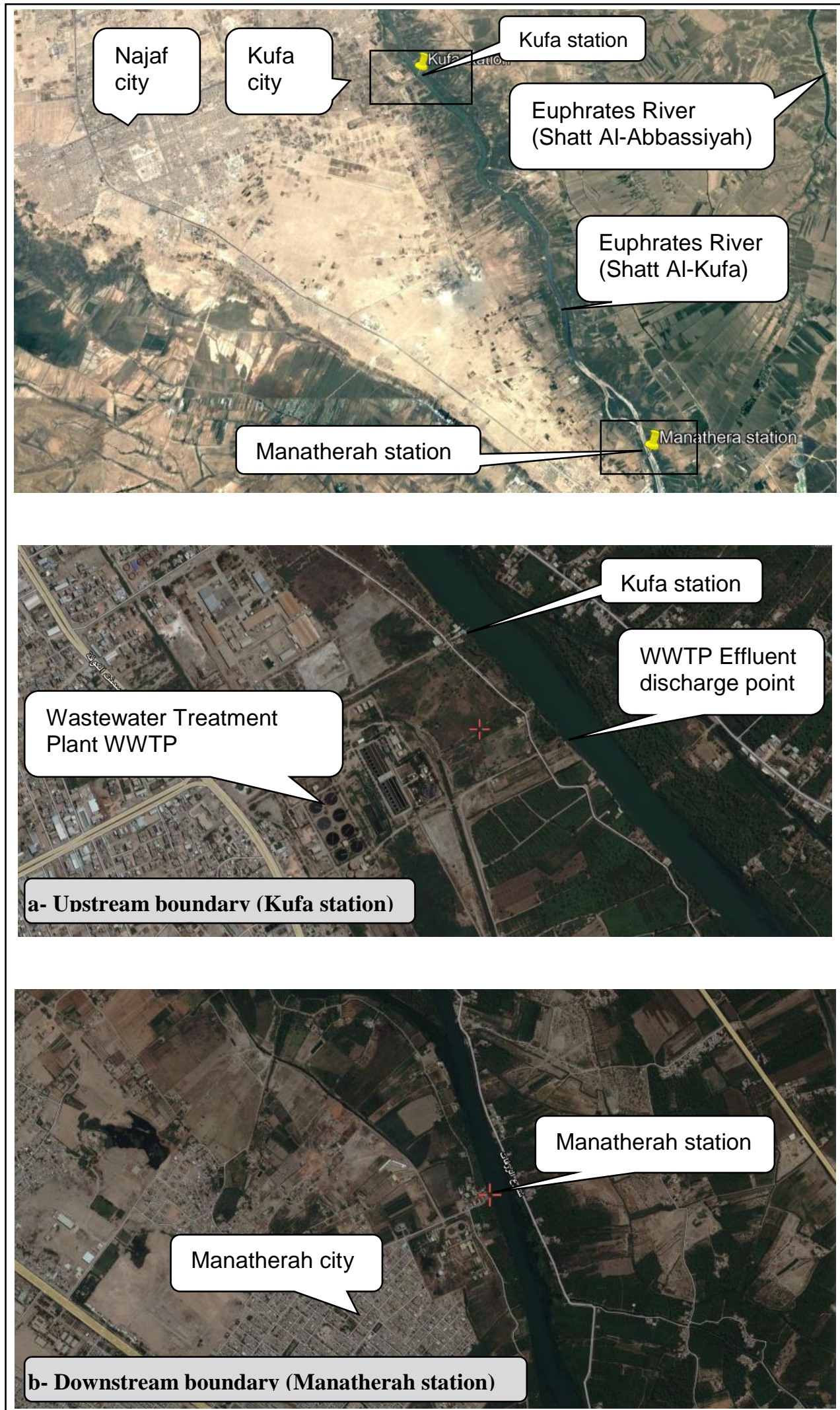

Fig. 1 Study area, a- Upstream boundary (Kufa station), b- Downstream boundary (Manathera station)

Shatt Al-Kufa is the main of the two branches. It passes through the historical Kufa city. Najaf and Kufa cities are supplied with water from Shatt Al-Kufa as a source for the drinking water, but they discharge into the river treated effluent of wastewater treatment plants that serve both of them. In fact, the plants are three. They adopt different treatment 


\section{International Advanced Research Journal in Science, Engineering and Technology}

Vol. 7, Issue 8, August 2020

\section{DOI 10.17148/IARJSET.2020.7825}

technologies as Trickling Filters, Activated Sludge and Integrated Fixed Film Activated Sludge. The total actual (working) capacity of the three plants is $82,000 \mathrm{~m}^{3} /$ day (serving 330,000 capita).

The upstream station (Kufa station) is located on $350 \mathrm{~m}$ upstream the discharge point of the treated effluent of wastewater treatment plant, whereas Manatherah station is located on $12.2 \mathrm{~km}$ downstream the discharge point. The selection of the upstream and downstream stations were to investigate the effect of the wastewater treatment plant on water quality and aquatic life of the river.

\section{METHODOLOGY}

The objective of this work was to investigate the effect of water pollution on some aspects of aquatic life. Independent variables studied were; the location of discharge point of WWTP treated effluent, flow rate of the river and season. Dependant variables (indicators) were water quality items and aquatic life response in the river. Location of the discharge point was downstream of Kufa station and upstream Manatherah station. So, comparing water quality parameters for water sample collected from the location of Kufa station and Manatherah station will explain the effect of the discharge point on water quality and then on aquatic life. Considering high and low flow rates of the river throughout the year counts for the effect of flow rate on both water quality and the life. Considering water quality for water samples collected through different seasons but with approximately equal flow rate will count for the effect of season. Extraneous variables like slightly varying quality and quantity of treated effluent discharged, other temporary local pollution sample. Although these variables are difficult to be controlled, but there effect is relatively limited.

\section{A. $\quad$ Field work}

Water temperature, $\mathrm{pH}$ and electric conductivity (EC) were measured using a thermometer, $\mathrm{pH}$ meter and EC meter in the field. Water samples collected daily from the river at the two stations (Kufa and Manatherah) along three intervals as 23-30 April 2019, 1-7 July 2019 and 10-18 November 2019. Boat was used to reach the centreline of the river for sampling. Sampling was carried out by means of polyethylene bottom sampler. Water samples were temporarily stored in one litre volume glass bottles with adding Hydrochloric acid drops to reserve the samples while transferring to lab. All plant species and vegetation cover values of all plant species were recorded in the study using the sectional method [17]. A survey of the aquatic vegetation cover was conducted through collecting plants within a specific area for qualitative analysis. Field surveys were conducted in the study and lists of all aquatic plants (salient, submerged and floating) were prepared, collected and classified. Marginal plants were also recorded in the study.

Several references have been adopted for the classification of aquatic plants, including Townsend et al.[18], Townsend and Guest [19], Saadi and Miah [20], and Al-Mayah and Al-Hamim [21]. During the botanical survey, the species in the study were photographed. The plant samples were collected after washing them with water in the study area to get rid of suspended materials. Samples were stored in plastic bags and in a container until they reached the laboratory.

\section{B. Laboratory work}

Water samples collected were analysed in lab for water quality parameters. Some of the parameters as total dissolved solids (TDS), total suspended solid (TSS), dissolved oxygen (DO), biochemical Oxygen demand BOD 5 , calcium (Ca), magnesium $(\mathrm{Mg})$ and sulphate $\left(\mathrm{SO}_{4}\right)$ were analysed according to the standard methods of the examination of water samples [22]. Other parameters as Nitrite $\left(\mathrm{NO}_{2}\right)$, Nitrate $\left(\mathrm{NO}_{3}\right)$ and phosphate $\left(\mathrm{PO}_{4}\right)$ were estimated following Parsons [23]. These parameters were tested to indicate the effect of discharging wastewater treated effluent in the river.

\section{RESULTS AND DISCUSSION}

The results obtained from field laboratory work are discussed here according to two branches; water quality parameters and some aspects of aquatic life like plants, fish and amphibians.

\section{A. Water Quality Parameters}

Results of water quality parameters tested as indicators are listed Table 1 . The values written in this table are averages (mean values) for $4-6$ daily test values. The main observation form Table 1 is the influence of flow rate in the river. As the flow rate increased during July, levels of EC, TDS, $\mathrm{BOD}_{5}, \mathrm{PO}_{4}, \mathrm{SO}_{4}, \mathrm{NO}_{2}$ and $\mathrm{NO}_{3}$ decreased obviously in both Kufa and Manathera stations (the whole study area). This is attributed to the fresh water released from Tharthar Lake. Iraqi Water Resources ministry, usually, release more flow rate in the Euphrates from Tharthar lake along the period of July month to support irrigation of certain crops (rice) in the middle parts of Iraq. The decrease in EC and TDS refer to increasing dilution capability of the river for the salt loading comes from neighbouring farm lands. The same attribution is accepted for $\mathrm{BOD}_{5}, \mathrm{PO}_{4}, \mathrm{SO}_{4}, \mathrm{NO}_{2}$ and $\mathrm{NO}_{3}$ decreased values, which was due to increasing river dilution factor for the organic loads added locally. The main distinguished source of organic load within the study area is the discharge point of treated effluent of Kufa Wastewater Treatment Plant. The effect of the plant may recognized by comparing the values 


\section{International Advanced Research Journal in Science, Engineering and Technology}

Vol. 7, Issue 8, August 2020

\section{DOI 10.17148/IARJSET.2020.7825}

of $\mathrm{BOD}_{5}, \mathrm{PO}_{4}, \mathrm{SO}_{4}, \mathrm{NO}_{2}$ and $\mathrm{NO}_{3}$ of Kufa station with Manathera station, even for July month. Values of DO certify the effect of the wastewater treated effluent. DO decreases with increasing organic load in water.

Values of TSS increased during July may due to increasing flow rate that caused some effect of scouring fine sediments from river bed. Parameters of water temperature, $\mathrm{pH}, \mathrm{Ca}$ and $\mathrm{Mg}$ did not show clear effect or trend. However, slight increase in $\mathrm{Ca}$ and $\mathrm{Mg}$ concentrations at Manathera when compared with Kufa in April and November may refer to the effect of the treatment plant.

TABLE I WATER QUALITY RESULTS (MEAN VALUES OF 4-6 READINGS)

\begin{tabular}{|c|c|c|c|c|c|c|}
\hline \multirow[t]{2}{*}{ Parameter } & \multicolumn{2}{|c|}{ 23-30 April, 2019} & \multicolumn{2}{|c|}{ 1-7 July 2019} & \multicolumn{2}{|c|}{ 10-18 November 2019} \\
\hline & Kufa st. & Manathera st. & Kufa st. & Manathera st. & Kufa st. & Manathera st. \\
\hline Flow, $\mathrm{m}^{3} / \mathrm{sec}$ & 84.1 & 83.3 & 205.8 & 205.7 & 62.3 & 61.5 \\
\hline Water temp. $\mathrm{C}^{0}$ & 16.2 & 16.3 & 38.0 & 38.2 & 13.7 & 13.6 \\
\hline $\mathrm{pH}$ & 7.2 & 7.4 & 7.5 & 7.6 & 7.2 & 7.3 \\
\hline $\mathrm{EC}, \mu \mathrm{s} / \mathrm{cm}$ & 825 & 881 & 463 & 486 & 709 & 732 \\
\hline TDS, ppm & 1065 & 1023 & 632 & 680 & 1012 & 995 \\
\hline TSS, ppm & 4.8 & 9.3 & 16.8 & 16.2 & 8.1 & 8.4 \\
\hline $\mathrm{DO}, \mathrm{ppm}$ & 5.6 & 4.8 & 9.8 & 9.6 & 7.4 & 6.8 \\
\hline $\mathrm{BOD}_{5}, \mathrm{ppm}$ & 4.2 & 6.6 & 0.9 & 1.8 & 1.2 & 1.6 \\
\hline $\mathrm{Ca}, \mathrm{ppm}$ & 96.6 & 120 & 108 & 96.2 & 92.5 & 110.8 \\
\hline $\mathrm{Mg}, \mathrm{ppm}$ & 69.7 & 88.4 & 81.5 & 78.3 & 73.8 & 112.5 \\
\hline $\mathrm{PO}_{4}, \mathrm{ppm}$ & 0.21 & 0.48 & 0.05 & 0.1 & 0.09 & 0.21 \\
\hline $\mathrm{SO}_{4}, \mathrm{ppm}$ & 676 & 730 & 87.4 & 107.4 & 452 & 486 \\
\hline $\mathrm{NO}_{2}, \mathrm{ppm}$ & 28.3 & 26.6 & 4.5 & 5.7 & 28.6 & 36.2 \\
\hline $\mathrm{NO}_{3}, \mathrm{ppm}$ & 0.08 & 0.9 & 0.02 & 0.06 & 0.15 & 0.4 \\
\hline
\end{tabular}

\section{B. Aspects of Aquatic Life}

Observations were made at dates $23^{\text {rd }}$ April, $1^{\text {st }}$ July and $10^{\text {th }}$ November for some aspects of aquatic life like plants, fish and amphibians as shown in Table 2, Table 3 and Table 4, respectively. Table 2 show that australis Phragmatis, Typha domingenis and Cyratophyllum demersum were higher at Manathera station when compared with Kufa station. This observation may belong to the organic content of water downstream of the wastewater plant discharge point. These plants make use of some sources of organic matter as fertilizers whiten certain concentrations. Other plants ( $L$ Syperus, pectinatus Potamogeton and Potamogeton crispus) did not show clear response for the wastewater effluent discharge point location.

TABLE 2 OBSERVATION RESULTS FOR PLANTS IN STUDY AREA

\begin{tabular}{|l|c|c|c|c|c|c|l|}
\hline \multirow{2}{*}{ Plant name } & \multicolumn{2}{|c|}{$\mathbf{2 3}^{\text {rd }}$ April, 2019 } & \multicolumn{2}{|c|}{$\mathbf{1}^{\text {st }}$ July 2019 } & \multicolumn{2}{|c|}{$\mathbf{1 0}^{\text {th }}$ Nov. 2019 } & $\begin{array}{c}\text { Common } \\
\text { Intensity }\end{array}$ \\
\cline { 2 - 8 } & Kufa st. & Manathera & Kufa st. & Manathera & Kufa st. & Manathera & Medium \\
\hline Phragmatis australis & 1500 & 1750 & 1700 & 2000 & 1500 & 1750 & Medium \\
\hline Typha domingenis & 1000 & 1200 & 1300 & 1500 & 1200 & 1200 & Medium \\
\hline Cyratophyllum demersum & 250 & 500 & 200 & 400 & 200 & 300 & Few \\
\hline Syperus L & 200 & 200 & 150 & 200 & 150 & 150 & Few \\
\hline Potamogeton pectinatus & 300 & 250 & 250 & 250 & 300 & 200 & Medium \\
\hline Potamogeton crispus & 400 & 500 & 300 & 300 & 400 & 400 & Medium \\
\hline
\end{tabular}

Table 3 show that Sharpeyi Barbus, Barbus xanthoptrrus, Barbus grypus, luteus Barbus and Liza abu observed with higher numbers at Kufa station when compared with Manathera station. This may reflect the trend of fish species to prefer zones of more fresh water upstream the discharge point of wastewater treatment plant effluent. This observation did not match what observed regarding Aspius vorax and Cyprinus carpio. The increased flow rate and dilution factor mentioned in (A) above may affect the trend of Barbus luteus during July.

General trend regarding the observed amphibians when compared with plants and fish. Table 4 show that all of the three amphibians (Bufo bufo spinosus, Testudo leprosa and Vepera lebetina) were observed with higher numbers at Manathera station as compared with Kufa station. This case may related to local other causes regarding life conditions of the three amphibians considered. 


\section{International Advanced Research Journal in Science, Engineering and Technology}

Vol. 7, Issue 8, August 2020

\section{DOI 10.17148/IARJSET.2020.7825}

TABLE 3 HUNTING AVAILABILITY OF FISH IN STUDY AREA

\begin{tabular}{|c|c|c|c|c|c|c|c|}
\hline \multirow[t]{2}{*}{ Fish type } & \multicolumn{2}{|c|}{ 23 $^{\text {rd }}$ April, 2019} & \multicolumn{2}{|c|}{$1^{\text {st }}$ July 2019} & \multicolumn{2}{|c|}{$1^{\text {th }}$ Nov. 2019} & \multirow{2}{*}{$\begin{array}{l}\text { Common } \\
\text { Intensity }\end{array}$} \\
\hline & Kufa st. & Manathera. & Kufa st. & Manathera & Kufa st. & Manathera & \\
\hline Sharpeyi Barbus & 3500 & 2800 & 4200 & 3500 & 2900 & 2250 & High \\
\hline Barbus xanthoptrrus & 1000 & 850 & 1500 & 700 & 800 & 550 & Medium \\
\hline Barbus grypus & 250 & 50 & 500 & 350 & 200 & 250 & High \\
\hline Barbus luteus & 1200 & 500 & 2000 & 2300 & 1500 & 1250 & Medium \\
\hline Aspius vorax & 25 & 30 & 60 & 45 & 30 & 35 & High \\
\hline Cyprinus carpio & 35 & 40 & 20 & 40 & 50 & 35 & Few \\
\hline Liza abu & 4000 & 3600 & 5200 & 4200 & 3600 & 3500 & High \\
\hline
\end{tabular}

TABLE 4 OBSERVATION RESULTS FOR AMPHIBIANS IN STUDY AREA

\begin{tabular}{|l|l|l|l|l|l|l|l|}
\hline \multirow{2}{*}{ Amphibians } & \multicolumn{2}{|c|}{$\mathbf{2 3}^{\text {rd }}$ April, 2019 } & \multicolumn{2}{c|}{$\mathbf{1}^{\text {st }}$ July 2019 } & \multicolumn{2}{c|}{$\mathbf{1 0}^{\text {th }}$ Nov. 2019 } & $\begin{array}{c}\text { Observed } \\
\text { number }\end{array}$ \\
\cline { 2 - 8 } & Kufa st. & Manathera. & Kufa st. & Manathera & Kufa st. & Manathera & High \\
\hline Bufo bufo spinosus & 2000 & 2500 & 1300 & 1500 & 1800 & 2200 & Medium \\
\hline Testudo leprosa & 50 & 65 & 60 & 75 & 45 & 60 & Few \\
\hline Vepera lebetina & 10 & 15 & 5 & 17 & 12 & 15 & (1) \\
\hline
\end{tabular}

\section{CONCLUSION}

According to results and observations of this study, the effluent of Kufa wastewater treatment plant had a slight local effect on some water quality parameters of the Euphrates river like EC, TDS, BOD $, \mathrm{DO}, \mathrm{PO}_{4}, \mathrm{SO}_{4}, \mathrm{NO}_{2}$ and $\mathrm{NO}_{3}$ that affected some aspects of aquatic life downstream the discharge point of the plant. Some kinds of fish like Sharpeyi Barbus, Barbus xanthoptrrus, Barbus grypus, luteus Barbus and Liza abu were observed with lower number just downstream the effluent discharge point.

\section{ACKNOWLEDGMENT}

The Directorate of Environmental Protection and Improvement which belong to Iraqi Ministry of Health and Environment supported this work. The directorate provided the author with some historical data for the study area. The Directorate of Water resources belonging to the Iraqi Ministry of Water Resources allowed the investigation to be carried out near Kufa and Manathera stations and facilitated the work by providing different facilitates, like boat, assistant workers, and flow rate reading at the two stations.

\section{REFERENCES}

[1] Al-Fatlawi A., Al-Jassani M. and Al-Rifaie J.” Pollution assessment of Euphrates River in three governances of Iraq", MATEC Web of Conferences 162, 05022 (2018), doi.org /10.1051/ matecconf /201816205022.

[2] Food and Agriculture Organization (FAO),"Water resources", 2017, available at: http://www.fao.org/nr/water/aquastat/water_res/index.stm.

[3] Abbas, A. A. and Hassan, F.M. "Water Quality Assessment of Euphrates River in Qadisiyah Province (Diwaniyah River), Iraq", Iraqi Journal of Agricultural Sciences -1028:49(2):152-162.

[4] Al-Ansari, N., Jawad S., Adamo N. and Sissakian V." Water Quality and its Environmental Implications within Tigris and Euphrates Rivers", Journal of Earth Sciences and Geotechnical Engineering, 9(4), 2019, 57-108

[5] Issa M. and Qanbar A.,"Assessment of Heavy Metal Contamination in Euphrates River Sediments from Al-Hindiya Barrage to Al-Nasiria City, South Iraq", Iraqi Journal of Science, 2016, 57 (1) A, pp: 184-193

[6] Hassan F. H, Saleh M. M. and Salman J. M. "A Study of Physicochemical Parameters and Nine Heavy Metals in the Euphrates River, Iraq", EJournal of Chemistry, 2010, 7(3), 685-692.

[7] Tweij Z.A.T, “Estimating of Some Heavy Metals in the River Water East of Kufa, The Province of Najaf”, Drug Invention Today, 13 (5), 2020.

[8] Al-Jwahery Z. A. W. and Hameed M. H. "Water Pollution in Karbala Province", International Journal of Advanced Research, 3 (2), 2015, pp. 433-455.

[9] Salman H. M. and Jasim M. N. “A GIS Assesment of Water Quality in Euphrates River/Iraq", Journal of Babylon University/Engineering Sciences, 23 (20), 2015.

[10] Ali khan H.A "Evaluation of Surface Water Quality in Al Kufa River Station", Al-Qadisiya Journal For Engineering Sciences, 5. (4), 2012, pp: 451-465.

[11] Noori M. M., Abdulrazzaq K. A. and Mohammed A. H.” Evaluation of Water Quality using Bhargava Water Quality Index Method and GIS, Case Study: Euphrates River in Al-Najaf City", International Journal of Science and Research, 6 (7), 2017, pp: 1286-1295.

[12] Dahmoshi A. O. M. and Alhadrawi H. A. N. "Bacteriological Study of Municipal Water Discharged in Al-Kufa River, Najaf, Iraq", Journal of Environmental Treatment Techniques, 8 (3), 2020, pp. 1168-1172.

[13] Bachmann A., Tice V., Al-Obeidi L. A. and Kilc D. T. "Tigris-Euphrates River Ecosystem: A Status Report", Paper for the Mesopotamia Water Forum 2019, Sulaymaniyah, Kurdistan Region of Iraq.

[14] Nashaat M. R., Rasheed K. A. and Hassan H. A.”Rotifera Abundance and Species Diversity in Al-Kufa River, Iraq", Global Journal of Science Frontier Research: H Environment \& Earth Science, 16 (5), 2016.

[15] Ali M. F., Salman A. H., Guda M. A., Abojassim A. A. and Almayahi B.” The Hydro Climatic Effects of Thermal Pollution on Surface waters in Iraq and its Biological Effects", Prensa Med Argent, 106 (2). 189. 


\section{International Advanced Research Journal in Science, Engineering and Technology}

Vol. 7, Issue 8, August 2020

\section{DOI 10.17148/IARJSET.2020.7825}

[16] Al-Ansari N., Admo N. and Sissakian V. K., "Hydrological Characteristics of the Tigris and Euphrates Rivers", Journal of Earth Sciences and Geotechnical Engineering,9 (4), 2019, pp.1-26.

[17] Canfield, R. "Application of Line Interception Method in Sampling Range Vegetation. Journal of Forestry, 39, 388-394, 1941.

[18] Townsend W.E., L.P. Witnauer, J.A. Riloff, C.E. Swift, "Comminuted meat emulsions: Differential thermal analysis of fat transitions", Food Technol., 22, 1968, pp. 319-323.

[19] Evan Guest and Townsend C., "Flora of Iraq. Volume 8, Monocotyledones Excluding Gramineae", Ministry of Agriculture \& Agrarian Reform, 1985.

[20] Al-saadi, H. A., \& Al-Mayah, A. A. “Aquatic plants of Iraq". Cent. Arab. Gulf. Univ. Basrah. 1983, (Arabic).

[21] Al-Mayah, A. A, \& Al- Hamim, F. I. (1991). "Aquatic plant, and the Algae (pp. 699-701). Univ. of Basra 1991, (Arabic).

[22] APHA, "Standard Method for the Examination of Water and Wastewater". $20^{\text {th }}$ Ed., American Public Health Association, Washington, DC, 1985.

[23] Parsons T R, Mait Y and Laulli C M, A manual of chemical and biological methods for seawater analysis, Pergamone Press Oxford, 1984.

\section{BIOGRAPHY}

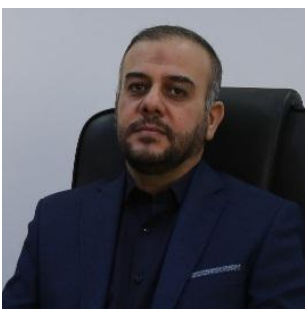

Assist. Prof. Dr. Hasan Mahdi M. Alkhateeb, Born in Najaf Ashraf-Iraq in 1971 and awarded B.Sc. in civil engineering in 1994 from College of Engineering, University of Mustansiriya in Baghdad, Iraq. The same University awarded Alkhateeb the M.Sc. in environmental engineering in 1997 and Ph.D. in Environmental Engineering in 2002. He designed a lot of water supply and sewerage projects for Iraqi cities including sewerage networks, pump stations and treatment plants. He prepared so many environmental assessment studies for a verity of industrial and services projects. He is now a faculty member at the Civil Engineering Department, Faculty of Engineering- University of Kufa, Iraq. He is the acting dean of the Faculty of Engineering in University of Kufa. His published research articles were in the fields of water resources, hydraulic structures and environmental engineering like preliminary and biological wastewater treatment, performance and hydraulics of pump stations, groynes and other hydraulic structurs.

Assist. Prof. Dr. Hasan Alkhateeb is consultant member of Environment Protection and Improvement Council in Najaf Ashraf Province, Iraq since 2004. He is a member of the scientific committee of the Civil Engineering Dep, University of Kufa. 